УДК 378

$10.17213 / 2075-2067-2021-2-50-62$

\title{
МОЛОДЫЕ УЧЕНЫЕ В РОССИИ: СОЦИАЛЬНО-ДЕМОГРАФИЧЕСКАЯ СТРУКТУРА И ОЦЕНКА СОЦИАЛЬНО-ПРОФЕССИОНАЛЬНЫХ АСПЕКТОВ ${ }^{1}$
}

\author{
(C) 2021 г. О. С. Иванченко
}

\section{Южно-Российский государственный политехнический университет (НПИ) имени М. И. Платова, г. Новочеркасск, Россия}

Цель исследования - статистический и соџиологический мониторинг количественно-качественной сочиально-демографической структуры молодых ученых и оченка социально-профессиональных аспектов с помощьюю расчета индекса удовлетворенности (I,).

Методологическая база исследования строится на концепции теории социальных групп как зарубежных классиков (Г. Зимемель, Г. Блумер, Э. Гидденс), так и отечественных сочиологов (О. И. Шкаратан, Г. А. Ястребов), в контексте которой сочиально-профессиональная группа рассматривается как сочиальный феномен соииального бытия в пространстве и времени, создающий предпосылки для профессионального взаимодействия и коммуникачии. Концепчия исследования строится на двух подходах: сочиологическом (молодые ученые рассматриваются как сочиально-профессиональная группа, где возраст является основной сущьностной характеристикой) и статистическом - характеризующем количественную сторону качественно определенных массовых сочиально-экономических процессов в структуре соииально-профессиональной группь молодых ученых в конкретный период времени (в рамках данного исследования анализировался период с 2000 года по настоящее время, при отсутствии данных на текущий период времени приводились имеющче максимально приближенные данные).

Результаты исследования. В ходе проведенного статистического анализа сделан вывод о затяжных стагнационных прочессах в сочииально-демографической структуре российских ученых. Отмечается, что при незначительном «притоке» молодежи в науке их качественные характеристики (наличие ученой степени кандидата или доктора наук) снижаются, что противоречит Стратегии научно-технологического развития России.

Перспективу исследования составляет углубленный анализ причинно-следственных связей в протекающих процессах в сочиально-демографической структуре молодых ученых и отрицательной динамики их количественно-качественных показателей, что будет способствовать определению ключевых ориентиров государственной научной политики.

Ключевые слова: молодые ученые; научная деятельность; сочиально-демографическая структура научных кадров.

1 Статья подготовлена в рамках гранта Президента Российской Федерации для государственной поддержки ведущих научных школ Российской Федерации на тему «Государственная политика в сфере высшего образования и развитие инновационного потенциала молодежи: экономические и неэкономические детерминанты и механизмы в условиях регионализации социального пространства и становления Индустрии 4.0» (НШ-2582.2020.6). 


\title{
YOUNG SCIENTISTS IN RUSSIA: SOCIO-DEMOGRAPHIC STRUCTURE AND ASSESSMENT OF SOCIO-PROFESSIONAL ASPECTS
}

\author{
(C) 2021 O. S. Ivanchenko
}

\section{Platov South Russian State Polytechnic University (NPI), Novocherkassk, Russia}

The purpose of the study is statistical and sociological monitoring of the quantitative and qualitative socio-demographic structure of young scientists and the assessment of socioprofessional aspects by calculating the satisfaction index (I).

The methodological basis of the study on the concept of the theory of social groups of both foreign classics (G. Zimemel, G. Bloomer, E. Giddens) and domestic sociologists (O. I. Shkaratan, G.A. Yastrebov). In the context of which socio-professional groups are considered as a social phenomenon of social existence in space and time, creating prerequisites for professional interaction and communication. The concept of the study is based on two approaches: sociological (young scientists are considered as a socio-professional group, where age is the main essential characteristic) and statistical — characterizing the quantitative side of qualitatively defined mass socio-economic processes in the structure of a socio-professional group of young scientists in a specific period of time (in the framework of this study, we considered the period from 2000 to the present, in the absence of data for the current period of time, the most approximate data were provided).

The results of the study. In the course of the conducted statistical analysis, a conclusion is made about the protracted stagnation processes in the socio-demographic structure of Russian scientists. It is noted that with a slight «influx» of young people in science, their qualitative characteristics (the presence of a candidate's or doctor's degree) decrease, which contradicts the Strategy of Scientific and Technological Development of Russia.

The prospect of the study. It makes an in-depth analysis of the cause-and-effect relationships of the ongoing processes in the socio-demographic structure of young scientists and the negative dynamics of their quantitative and qualitative indicators, which will help to determine the key guidelines of the state scientific policy.

Key words: young scientists; scientific activity; socio-demographic structure of scientific personnel.

Введение. Проблемы кадрового обеспечения российской науки уже достаточно продолжительное время стоят в повестке экспертного и научного сообщества. Стагнационные процессы, начавшиеся в 1990-е годы, обусловлены как социально-экономическим и политическим кризисом, так и утратой целевых ориентиров реализуемой модели государственного управления наукой. Проблемы снижения динамики численности занятых в науке, сокращения притока молодежи в науку, оттока из науки работников наиболее продуктивного возраста не только не были решены, но и приобрели черты стагнации, научная деятельность не привлекательна для молодых научных кадров ввиду низкого уровня престижности и неразвитости рынка труда в сфере исследований и разработок. Данная ситуация в условиях экономики, основанной на знаниях, когда именно наука должна стать социально-экономическим драйвером развития государства и общества, не допустима. В связи с этим необходим систематический статистический и социологический мониторинг, который позволит контролировать состояние и динамику количественно-качес- 
твенного состава ученых (исследователей), своевременно выявлять проблемы и лучшие институциональные практики, перспективные в национальном контексте.

\section{Результаты исследования}

Сочиально-демографические характеристики молодых ученых как сочиально-профессиональной группь

Социальные группы являлись предметом исследования многих западных социологов $[2,4,7]$, в русле которой социальная группа рассматривается как «любая совокупность индивидов, объединенных общими интересами, находящимися во взаимодействии, оказывающих друг другу помощь в достижении личных целей» [22, с. 321-322]. В отечественной социологии социальная группа рассматривается как элемент социальной структуры, типичной формы бытия в обществе распространенного множества каких-либо субъектов, обладающих устойчивым сходным положением [20]. Среди социальных групп выделяют социально-профессиональные группы - сообщества, объединенные одной профессиональной деятельностью, члены которых имеют совместное бытие в пространстве и времени, создающие предпосылки для профессиональной коммуникации между людьми, общие разделяемые всеми членами культурно-нравственные и морально-этические нормы $[1,11]$.

Социологический подход к изучению молодых ученых как социально-профессиональной группы является интегральным и предполагает наличие у членов группы общего характера и вида труда, схожего со- циального статуса, чувства идентичности с другими членами общества, включая особую профессиональную культуру. Молодежь в сфере науки является специфической социально-профессиональной группой, отображающей специфику развития научнопрофессионального сообщества, осуществляющего научную, научно-инновационную и научно-исследовательскую деятельность. Выделение социально-профессиональных групп определяется способностью к самовоспроизводству, что обеспечивает репродуцируемость группы как условия, определяющего устойчивость наряду с необходимой изменчивостью наблюдаемого разнообразия потребностей и ценностей [27]. Молодые ученые отображают специфику развития не только молодежи в целом, но и профессионального сообщества, и идентифицируются по возрастному критерию, установленному в соответствии с Распоряжением Правительства РФ от 29.11.2014 г. №2403-p [14]. Таким образом, объектом данного исследования являются молодые ученые (исследователи, в том числе и аспиранты) до 30 лет (без ученой степени), до 35 лет (со степенью кандидата наук, в том числе и докторанты) до 40 лет (со степенью доктора наук).

Количественно-качественные характеристики исследования молодых ученых как сочиально-демографической группь

Количественный анализ исследуемой группы необходимо начать с динамики общей численности исследователей (рис. 1), которая на протяжении исследуемого периода имеет устойчивую тенденцию к снижению, а если сравнивать численность исследователей, на-

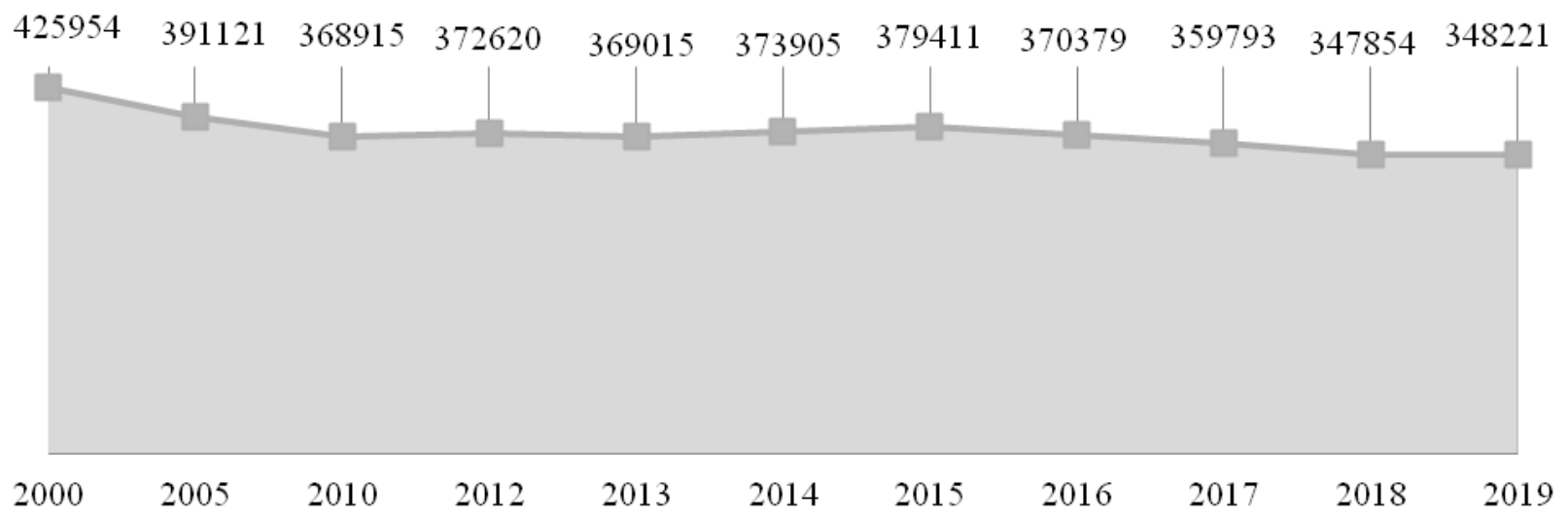

Pис. 1. Динамика общей численности исследователей [8] 
пример, с 1995 годом (в данный период численность исследователей составляла 1061044 тыс. человек), то динамика имеет ярко выраженную стагнацию [8].

Переходя к анализу статистических данных в разбивке по возрастной структуре, можно заметить, что доля молодых ученых в общей численности увеличивается (особенно в возрастной когорте 30-39 лет), но учитывая законодательно установленные возрастные критерии для молодых ученых (без степени - 30 лет, кандидат наук - 35 лет, доктор наук - 40 лет), кандидат наук старше 35 лет уже не является молодым ученым, а более всего исследователей с ученой степенью кандидатов наук находятся в возрастной группе 35-39 лет, которых уже нельзя отнести к категории молодых ученых. Наиболее сложная ситуация в возрастной группе до 29 лет. Несмотря на общее увеличение численности исследователей в данной возрастной группе, качественные изменения в этой группе не наблюдаются (соискание степени кандидата и тем более доктора наук на протяжении почти двух десятков лет не наблюдается) (табл. 1). Следует особо подчеркнуть, что из общей численности исследователей лишь $28,7 \%$ имеют ученую степень кандидата или доктора наук $[8,9]$.

По состоянию на 2019 год наибольшая доля кандидатов наук находится в возрастной когорте 35-39 лет (14,5\%), которая уже не относится к категории молодых ученых. В возрастной когорте 20-34 года кандидатов наук - $12,9 \%$, а до 29 лет — лишь 2,8 \%. От- носительно молодых докторов наук ситуация крайне сложная: наибольшая доля докторов находится в возрастной когорте 70+ $(36,7 \%)$, что касается молодых ученых со степенью доктора наук в возрасте 30-34 года, их всего 0,4\%, до 29 лет - 0,048 \%. Данные, приведенные в таблице 1, свидетельствуют о том, что ситуация с молодыми докторами наук на протяжении почти 20 лет остается неизменной. Общая численность докторантов сократилась в 4,6 раза (с 4418 тыс. человек в 2010 году до 955 человек в 2019 году). Если анализировать возрастные показатели докторов наук за исследуемый период, то можно сказать, что средний возраст докторанта за девять лет увеличился с 62 лет в 2010 году до 64 лет в 2019 году [13]. Больше всего докторантов находится возрастной категории 40-49 лет (по состоянию на 2019 год), в 2010 году наиболее многочисленная возрастная категория докторантов была в когорте до 34 лет.

Анализируя численный состав аспирантов, которые представляют собой особую группу молодых ученых, поскольку с этой группой связываются перспективы воспроизводства научно-исследовательского потенциала общества и кадрового состава работников научных учреждений и обучение в аспирантуру рассматривается как ступень подготовки научных кадров, стоит отметить, что ситуация стоит достаточно остро, как с точки зрения численности аспирантов, так и с точки зрения эффективности работы аспирантуры - завершение обучения в аспирантуре должно заканчиваться защитой кандидатской диссертации.

\section{Возрастная структура исследователей, \% $[8,9]$}

Таблица 1

\begin{tabular}{|l|c|c|c|c|c|c|c|c|c|}
\hline \multirow{2}{*}{$\begin{array}{c}\text { Возрастная } \\
\text { структура }\end{array}$} & \multicolumn{9}{|c|}{ Научный статус } \\
\cline { 2 - 11 } & \multicolumn{2}{|c|}{ Доля кандидатов наук } & \multicolumn{2}{|c|}{ Доля докторатов наук } & \multicolumn{2}{|c|}{ Доля исследователей } \\
\cline { 2 - 11 } & 2000 & 2006 & 2019 & 2000 & 2006 & 2019 & 2000 & 2006 & 2019 \\
\hline $\begin{array}{l}\text { До 29 лет } \\
\text { включительно }\end{array}$ & 2,7 & 4,5 & 2,4 & 0,05 & 0,1 & 0,04 & 10,6 & 17 & 16,8 \\
\hline $30-39$ лет & 12,4 & 14,3 & 27,4 & 1,8 & 1,8 & 2 & 15,6 & 13,1 & 27,4 \\
\hline $40-49$ лет & 25,1 & 18,8 & 22 & 14,1 & 11,3 & 9,8 & 26,1 & 19 & 16 \\
\hline $50-59$ лет & 29,2 & 29 & 16 & 27,9 & 29,9 & 17,4 & 26,9 & 27,8 & 14,9 \\
\hline $60-69$ лет & 26 & 23,8 & 18,3 & 38,9 & 32,4 & 33,4 & 17,7 & 17,2 & 15,8 \\
\hline $70+$ & 4,6 & 9,7 & 13,5 & 17,3 & 24,7 & 36,7 & 3,1 & 5,9 & 9 \\
\hline
\end{tabular}


В период с 2010 по 2019 годы сократилась численность как аспирантов (с 157437 тыс. человек в 2010 году до 84262 тыс. человек в 2019 году), так и организаций, где функционировала аспирантура (с 1568 в 2010 году до 1223 в 2018 году) (табл. 2). Результативность аспирантуры оценивается по количеству защищенных аспирантами диссертаций. Если сравнивать исследуемые периоды, то в 2019 году результативность обучения в аспирантуре равна $10,5 \%$, в то время как в 20002013 годах данный показатель варьировался от $24,0 \%$ до $33,5 \%$. Основная возрастная когорта обучающихся в аспирантуре - 25-29 лет (47816 тыс. человек), в возрастной когорте до 24 лет обучается 17293 тыс. человек [8].

Если рассматривать возрастную структуру аспирантов как будущих ученых, то следу- ет отметить, что возрастной критерий идентификации с молодыми учеными имеет высокое значение - 28,5 лет, но при этом наиболее многочисленная возрастная группа -25 лет (14585 по состоянию на 2019 год). Общая численность аспирантов в период с 2010 года по 2019 сократилась в 1,9 раза (с 157437 тыс. чел. до 84265 тыс. чел.).

Учитывая значительные территориальные масштабы нашей страны, целесообразно проанализировать количественно-качественные характеристики молодых ученых по территориальному принципу. Социально-демографическая структура молодых научных кадров достаточно неравномерна в разбивке по федеральным округам. Лидером по общей численности исследователей выступает Центральный федеральный округ (177343 тыс.

\section{Подготовка научных кадров [8]}

Таблица 2

\begin{tabular}{|c|c|c|c|c|}
\hline Год & $\begin{array}{c}\text { Численность организаций, } \\
\text { осуществляющи подготовку } \\
\text { аспирантов }\end{array}$ & $\begin{array}{c}\text { Численность } \\
\text { аспирантов, } \\
\text { тыс. чел }\end{array}$ & $\begin{array}{c}\text { Выпуск } \\
\text { изпирантуры, } \\
\text { тыс. чел }\end{array}$ & $\begin{array}{c}\text { Выпуск с защитой } \\
\text { диссертации, } \\
\text { тыс. чел }\end{array}$ \\
\hline 2010 & 1568 & 157437 & 33763 & 9611 \\
\hline 2015 & 1446 & 109936 & 25826 & 4651 \\
\hline 2018 & 1223 & 90823 & 17729 & 2198 \\
\hline
\end{tabular}

\begin{tabular}{|c|c|c|c|c|c|c|}
\hline Средний возраст & 62 & 62,5 & \multicolumn{2}{|c|}{63} & \multicolumn{2}{|c|}{64} \\
\hline до 34 лет & \multicolumn{2}{|c|}{1307} & & 207 & 238 & 244 \\
\hline 35-39 лет & \multicolumn{2}{|c|}{1117} & \multicolumn{2}{|c|}{285} & 304 & 241 \\
\hline 40-49 лет & \multicolumn{2}{|c|}{1113} & 264 & \multicolumn{2}{|c|}{329} & 338 \\
\hline 50-54 года & \multicolumn{3}{|c|}{481} & \multicolumn{2}{|c|}{66} & 68 \\
\hline 55-59 лет & \multicolumn{2}{|c|}{263} & & \multirow[t]{2}{*}{46} & 56 & 47 \\
\hline 60 и старше & \multicolumn{2}{|c|}{137} & 53 & & 59 & 37 \\
\hline Всего & \multicolumn{2}{|c|}{4418} & & & 1059 & 955 \\
\hline
\end{tabular}

Рис. 2. Возрастная структура докторантов (кол. человек) [23] 
2021. № 2

Таблица 3

\section{Доля молодых ученых по федеральным округам Российской Федерации} (данные приведены по состоянию на 2019 год) [9, 12]

\begin{tabular}{|c|c|c|c|c|}
\hline Федеральный округ & $\begin{array}{c}\text { Общая } \\
\text { численность } \\
\text { исследователей }\end{array}$ & $\begin{array}{c}\text { Доля } \\
\text { исследователей } \\
\text { до } 39 \text { лет }\end{array}$ & $\begin{array}{c}\text { Доля } \\
\text { исследователей } \\
\text { до } 39 \text { лет, } \\
\text { имеющих } \\
\text { ученую степень }\end{array}$ & $\begin{array}{c}\text { Средний } \\
\text { возраст } \\
\text { исследователя }\end{array}$ \\
\hline $\begin{array}{l}\text { Центральный } \\
\text { федеральный округ }\end{array}$ & 177343 & 41,6 & 6,3 & 47 \\
\hline $\begin{array}{l}\text { Северо-Западный } \\
\text { федеральный округ }\end{array}$ & 46446 & 44,2 & 5,6 & 46 \\
\hline $\begin{array}{l}\text { Южный } \\
\text { федеральный округ }\end{array}$ & 12912 & 43,2 & 8,1 & 45 \\
\hline $\begin{array}{l}\text { Северо-Кавказский } \\
\text { федеральный округ }\end{array}$ & 4140 & 32,9 & 15,7 & 48 \\
\hline $\begin{array}{l}\text { Приволжский } \\
\text { федеральный округ }\end{array}$ & 52992 & 51,7 & 5,1 & 42 \\
\hline $\begin{array}{l}\text { Уральский } \\
\text { федеральный округ }\end{array}$ & 22162 & 50,4 & 5,2 & 43 \\
\hline $\begin{array}{l}\text { Сибирский } \\
\text { федеральный округ }\end{array}$ & 25034 & 46,8 & 11,9 & 45 \\
\hline $\begin{array}{l}\text { Дальневосточный } \\
\text { федеральный округ }\end{array}$ & 7192 & 34,8 & 12,4 & 48 \\
\hline Российская Федерация & 348221 & 44,2 & 6,7 & 46 \\
\hline
\end{tabular}

$$
\begin{array}{r}
\text { Средннй возраст } \\
\text { до } 22 \text { лет } \\
23 \text { года } \\
24 \text { года } \\
25 \text { лет } \\
26 \text { лет } \\
27 \text { лет } \\
28 \text { лет } \\
29 \text { лет } \\
30-34 \text { года } \\
35-39 \text { лет } \\
40 \text { и старше }
\end{array}
$$

Всего

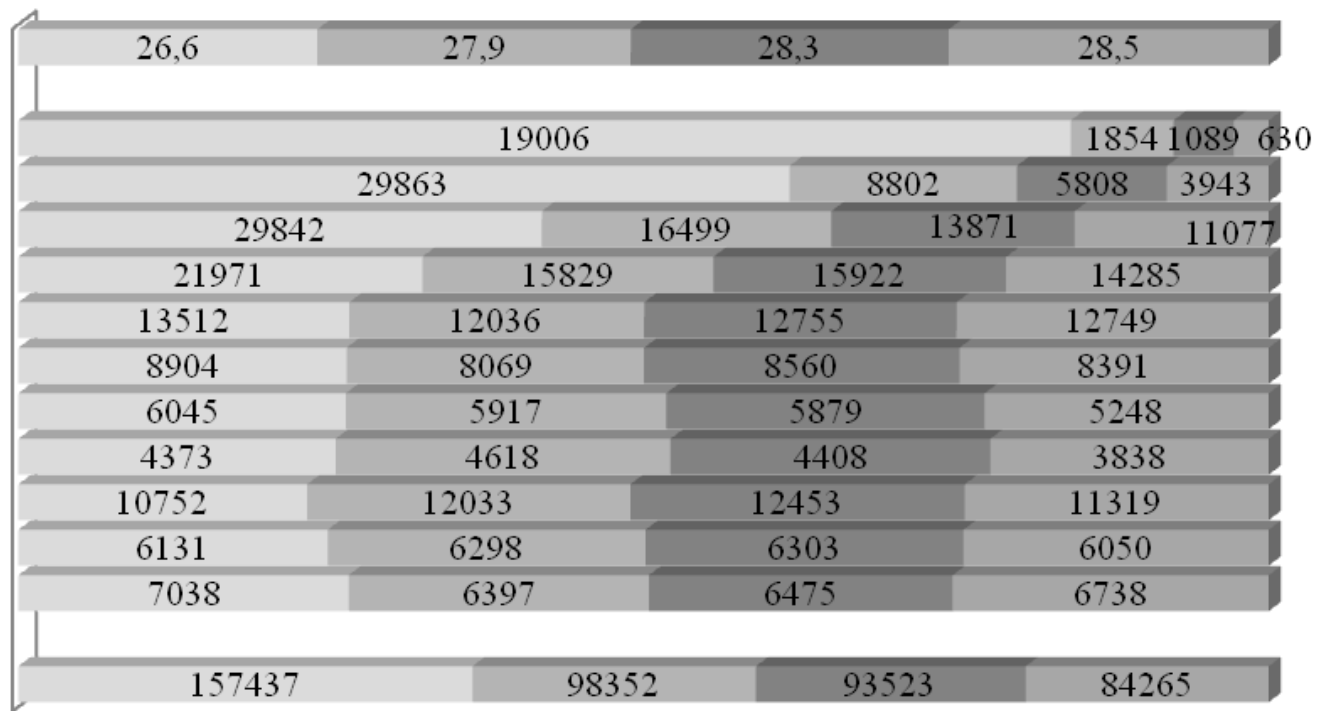

Рис. 3. Возрастная структура аспирантов [23] 
человек), по доле исследователей до 39 лет Приволжский и Уральский федеральные округа (51,7\% и 50,4\% соответственно), по доле молодых исследователей до 39 лет, имеющих ученую степень, лидируют Северо-Кавказский (при самой низкой общей численности исследователей и доле молодых исследователей до 39 лет) и Дальневосточный федеральные округа (15,7\% и 12,4\% соответственно), самый низкий показатель среднего возраста исследователя - 42 года - в Приволжском федеральном округе (табл. 3) $[9,12]$.

В 2019 году лидерами по подготовке научных кадров среди федеральных округов являются Центральный (34286 тыс. человек) и Приволжский федеральные округа (12771 тыс. человек). Указанные федеральные округа являются также абсолютными лидерами по выпуску аспирантов с защитой диссертации (716 и 246 человек соответственно) (табл. 4) [9, 12, 19].

Статистический анализ социально-демографической структуры научных кадров свидетельствует о сокращении общей численности исследователей в период с 2000 по 2019 год в 1,22 раза. Наметилась тенденция к увеличению доли молодых исследова- телей в общей численности научных кадров (c 10,6\% в 2000 году до 16,8\% в 2019 году), однако данный сдвиг пока не может переломить затяжное «старение» научного персонала. Анализ качественного состава молодых ученых имеет достаточно скромные показатели, в общей численности исследователей лишь 28,7\% имеют ученую степень кандидата или доктора наук. В возрастной когорте до 29 лет доля ученых со степенью кандидата наук сократилась за исследуемый период с 2,7\% до 2,4\%. Рассматривая научный статус доктора наук в возрасте до 29 лет, можно сказать, что в динамике изменений нет, однако следует отметить: данный феномен (наличие научного статуса доктора наук до 29 лет), скорее, исключение и носит единичный характер, поэтому особое внимание следует обратить на возрастную когорту 30-39 лет, где ситуация остается неизменной, и 40-49 лет, где наблюдается отрицательная динамика сокращения численности с 14,1\% до 9,8\% за исследуемый период.

Анализируя количественно-качественные показатели, характеризующие аспирантов как особую группу молодых ученых, стоит отметить, что наблюдается яркая выра-

Таблица 4

\section{Подготовка научных кадров в разбивке по федеральным округам (данные приведены по состоянию на 2019 год) $[9,12,19]$}

\begin{tabular}{|l|c|c|c|}
\hline \multicolumn{1}{|c|}{ Федеральный округ } & $\begin{array}{c}\text { Общая } \\
\text { численность } \\
\text { аспирантов }\end{array}$ & $\begin{array}{c}\text { Выпуск } \\
\text { из аспирантуры }\end{array}$ & $\begin{array}{c}\text { Выпуск } \\
\text { с защитой } \\
\text { диссертации }\end{array}$ \\
\hline $\begin{array}{l}\text { Центральный } \\
\text { деральный округ }\end{array}$ & 34286 & 6445 & 716 \\
\hline $\begin{array}{l}\text { Северо-Западный } \\
\text { федеральный округ }\end{array}$ & 11246 & 1971 & 197 \\
\hline Южный федеральный округ & 6291 & 1215 & 60 \\
\hline $\begin{array}{l}\text { Северо-Кавказский } \\
\text { федеральный округ }\end{array}$ & 2984 & 546 & 246 \\
\hline $\begin{array}{l}\text { Приволжский } \\
\text { федеральный округ }\end{array}$ & 12771 & 2403 & 48 \\
\hline Уральский федеральный округ & 4686 & 796 & 207 \\
\hline Сибирский федеральный округ & 9191 & 1578 & 1622 \\
\hline $\begin{array}{l}\text { Дальневосточный } \\
\text { федеральный округ }\end{array}$ & 2807 & 499 & \\
\hline Российская Федерация & 84265 & 15453 & 28 \\
\hline
\end{tabular}


женная тенденция сокращения численности в 1,73 раза, уменьшается количество защит аспирантов после выпуска из аспирантуры в 4,4 раза, также увеличивается средний возраст аспиранта с 26,6 лет в 2010 году до 28,5 лет в 2019 году.

В разбивке по федеральным округам по общей численности исследователей на первом месте находится Центральный федеральный округ, по доле молодых исследователей до 39 лет лидируют Приволжский и Уральский федеральные округа, по качественным характеристикам молодых ученых (наличие ученой степени кандидата или доктора наук) впереди всех Северо-Кавказский и Дальневосточный федеральные округа.

Поиск причин отрицательной динамики численности молодых ученьх.

В рамках государственного управления наукой реализуется целый комплекс институций, государственных программ (например, Национальный проект «Наука», программа «Научно-технологическое развитие Российской Федерации») и инструментов (гранты Президента Российской Федерации [25], гранты Правительства Российской Федерации [18], гранты Президента Российской Федерации для государственной поддержки молодых российских ученых и по государственной поддержке ведущих научных школ Российской Федерации [17]), однако ситуация «вымывания» и «оттока» молодых научных кадров продолжает быть актуальной.

Указанные противоречия легли в основу социологического исследования, проведенного на территории Южного федерального округа среди молодых ученых. Расчет выборочной совокупности производился методом простого случайного отбора по схеме бесповторного с квотным отбором единиц и составил 703 человека. Выборочная совокупность включала следующие единицы наблюдения: исследователи (представители научно-исследовательских институтов), исследователи (представители вузовской науки), докторанты, аспиранты.

В рамках исследования для каждой группы был рассчитан индекс удовлетворенности (I $)$ различными социально-профессиональными аспектами. Для вычислений $\mathrm{I}_{\mathrm{y}}$ использовалась пятибалльная шкала, где 1 - минимальное значение удовлетворенности, 5 - максимальное значение удовлетворенности, применим следующую формулу:

$$
\mathrm{I}_{\mathrm{y}}=\frac{1 \cdot(-1)+2 \cdot(-0,5)+3 \cdot 0+4 \cdot(0,5)+5 \cdot 1}{1+2+3+4+5},
$$

где значения 1, 2, 3, 4, 5 соотносятся с числом ответов под данными пунктами. Расчет индекса удовлетворенности имеет следующую интерпретацию. Если число молодых ученых, удовлетворенных рассматриваемыми аспектами жизни (балл 4 и 5), превышает 2/3 всех опрошенных респондентов, такой результат считается благополучным (удовлетворительным). Обратная ситуация, в которой 2/3 опрошенных высказали неудовлетворение аспектами жизни (балл 1 и 2), свидетельствует о кризисной ситуации, в перспективе ведущей к нарушению нормального протекания социальных процессов. Результаты расчета приведены в таблице 5.

Результаты расчета индекса удовлетворенности (I) свидетельствуют о глубоком кризисе в группе аспирантов. Это касается как индивидуального материального благополучия, так и институциональной материально-технической базы. Более всего данная группа респондентов удовлетворена социальными связями (кругом общения и окружения $\left.\left(\mathrm{I}_{\mathrm{y}}=0,34\right)\right)$. Проблемы эффективности работы аспирантуры и аспирантов находят в повестке дня экспертного и научного сообщества уже достаточно продолжительное время, однако, видимого результата стабилизации в сложившейся ситуации не наблюдается. Это связано как с кризисом российской аспирантуры [24], так и с трансформационными процессами института аспирантуры в российском поле образования $[10,15,26]$, престижностью профессии «ученого» в обществе [21].

Более всего удовлетворены социально-профессиональными аспектами представители вузовской науки. Отрицательное значение индекса удовлетворенности среди всех исследуемых групп имеет инфраструктурное обеспечение проведения научных исследований $\left(\mathrm{I}_{\mathrm{y}}=-0,13\right)$. Слабое ресурсное оснащение научных исследований является одним из основных факторов сдерживания развития отечественных исследований, как следствие этого - уход молодежи из науки (в том числе и эмиграция молодых научных кадров). Ключевыми проблемами молодых 
российских ученых (неудовлетворенность социально-профессиональными аспектами) является материальное обеспечение (уровень заработной платы $\left.I_{\text {y }}=0,03\right)$, инфраструктурное обеспечение $\left(\mathrm{I}_{\mathrm{y}}=-0,13\right)$, реализация профессионального потенциала $\left(\mathrm{I}_{\mathrm{y}}=0,25\right)$. Следует отметить, что идентичные проблемы кадрового обеспечения российской науки подробно анонсировались И.Г. Дежиной еще 2005 году в докладе «Кадровые проблемы в российской науке и инициативы государства» [5] на международном симпозиуме «Молодые ученые и преемственность поколений в науке». Однако исследования, проведенные в текущий период времени [3, 6], в том числе и авторское социологическое исследование и статистический анализ, фиксируют аналогичные проблемы в более обостренной форме.
Заключение. Тенденция «утечки мозгов», «оттока» молодежи из науки, начавшаяся в конце 1990 - начале 2000 годов, по-прежнему актуальна для нашего государства. Несмотря на сформированную систему стратегического управления наукой, реализуемый комплекс нормативно-правовых актов, функционирование государственных органов управления, научных организаций, действия финансовых механизмов поддержки научной деятельности (система фондовой и грантовой поддержки научных исследований), проблема кадрового обеспечения, воспроизводства и преемственности в науке остается вызовом для нашего государства. Основной вывод проведенного исследования заключается в том, что, несмотря на развитость институциональной среды российской науки, мер государственной поддержки, направленных

Таблица 5

Индекс удовлетворенности молодыми учеными различными социально-профессиональными аспектамиำ

\begin{tabular}{|l|c|c|c|c|c|}
\hline \multirow{2}{*}{\begin{tabular}{c} 
Социально- \\
\multirow{2}{*}{$\begin{array}{c}\text { профессиональные } \\
\text { аспекты }\end{array}$}
\end{tabular}} & $\begin{array}{c}\text { Представители } \\
\text { вузовской науки }\end{array}$ & $\begin{array}{c}\text { Представители } \\
\text { НИИ }\end{array}$ & Докторанты & Aспиранты & $\begin{array}{c}\text { Общий } \\
\text { индекс } \\
\text { по всем } \\
\text { группам }\end{array}$ \\
\hline $\begin{array}{l}\text { Материальная } \\
\text { обеспеченность }\end{array}$ & 0,29 & $-0,08$ & 0,07 & $-0,21$ & 0,03 \\
\hline $\begin{array}{l}\text { Социальный } \\
\text { статус }\end{array}$ & 0,56 & 0,16 & 0,5 & 0,07 & 0,25 \\
\hline $\begin{array}{l}\text { Профессиональ- } \\
\text { ный статус }\end{array}$ & 0,51 & 0,08 & 0,56 & 0,03 & 0,2 \\
\hline $\begin{array}{l}\text { Профессиональ- } \\
\text { ный выбор }\end{array}$ & 0,86 & 0,48 & 0,71 & 0,27 & 0,51 \\
\hline $\begin{array}{l}\text { Реализация про- } \\
\text { фессионального } \\
\text { потенциала }\end{array}$ & 0,32 & 0,21 & 0,12 & $-0,09$ & 0,25 \\
\hline $\begin{array}{l}\text { Круг общения, } \\
\text { окружение }\end{array}$ & 1 & 0,66 & 1 & 0,34 & 0,64 \\
\hline $\begin{array}{l}\text { Инфраструктур- } \\
\text { ное обеспечение }\end{array}$ & 0,04 & $-0,2$ & $-0,14$ & $-0,37$ & $-0,13$ \\
\hline Жизнь в целом & 0,7 & 0,36 & 0,5 & 0,08 & 0,37 \\
\hline
\end{tabular}

2 Интерпретация значения индекса: значение «-1» минимальный уровень удовлетворенности, значение «1» - максимальный уровень удовлетворенности. 
на развитие науки, на сегодняшний день недостаточно. Особого внимания требуют вопросы социальной поддержки молодых ученых, в особенности аспирантов как наиболее уязвимой группой в научном сообществе.

\section{Литература}

1. Борисова С.Н. Теоретико-методологические подходы к изучению профессий и профессиональных групп в западной социологии // Вестник Нижегородского университета им. Н.И. Лобачевского. Сер. Социальные науки. - 2012. - №2 (26). - С. 7-14.

2. Блумер Г. Коллективное поведение // Американская социологическая мысль: Тексты. — М., 1994.

3. Горшков М.К., Шереги Ф.Э. Молодежь России в зеркале социологии. К истокам многолетних исследований. - М.: ФНИСЦPAH, 2020. - Ст. 393-397.

4. Гидденс Э. Устроение общества: Очерки теории структурации. - 2-е изд. - М., 2005. - $528 \mathrm{c}$.

5. Дежина И.Г. Кадровые проблемы в российской науке и инициативы государства // Наука и науковедение. - 2006. №1. - C. 28-34.

6. Долюенко Р.А., К Карпилянский В.А., Хади Р. А., Диденко А. С. Мотивация молодых ученых к научно-исследовательской деятельности в российских региональных вузах // Образование и наука. - 2019. - Т. 21. №9. - C. 122-153.

7. Зиммель Г. Избранное: В 2 т. - М., 1996. - T. 2. - 1283 c.

8. Индикаторы науки - 2020: стат. сб. / Л. М. Гохберг, К. А. Дитковский, Е. И. Евневич и др.; Нац. исслед. ун-т «Высшая школа экономики». - М.: НИУ ВШЭ, 2020. $337 \mathrm{c}$.

9. Инновационное развитие Российской федерации в 2019 году. Аналитический отчет ФГБНУ НИИ РИНКЦЭ. 2020. [Электронный pecypc]. - Режим доступа: http://www.miiris. ru/digest/analitika_RF.pdf (Дата обращения: 23.01.2021).

10. Малошонок Н.Г. «Студент» или «молодой ученый»: мнения научных руководителей о предпочтительной модели аспирантской подготовки в российских университетах // Мониторинг общественного мнения:
Экономические и социальные перемены. 2019. - №4. - С. 278-303.

11. Мансуров В.А. Юрченко О. В. Социология профессиональных групп: история становления и перспективы // Вестник Института социологии. - 2013. - №7. - С. 92-106.

12. Научно-инновационный потенциал Южного федерального округа: стат. сб. / В.П. Заварухин, И. В. Зиновьева, С.Н. Иноземцева и др. - М.: ИПРАН РАН, 2018. $155 \mathrm{c}$.

13. Научные кадры: тенденция снижения сохраняется [Электронный ресурс] / Экспресс-выпуск от 25.09.2019 г. Институт статистических исследований и экономики знаний. НИУ ВШЭ. - Режим доступа: https:// issek.hse.ru/data/2020/02/07/1574269460/ NTI_N_145_25092019.pdf (Дата обращения: 23.01.2021).

14. Основы государственной молодежной политики Российской Федерации до 2025 года. Утверждена распоряжением Правительства РФ от 29.11.2014 г. №2403-р.

15. Официальный сайт службы государственной статистики [Электронный ресурс]. - Режим доступа: https://rosstat.gov.ru/ (Дата обращения: 23.01.2021).

16. Портрет современного российского аспиранта / С.К. Бекова, И.А. Груздев, 3.И. Джафарова, Н.Г. Малошонок, Е.А. Терентьев. - М.: НИУ ВШЭ, 2017. - 60 с.

17. Постановление Правительства Российской Федерации от 27 апреля 2005 года №260 «O мерах государственной поддержки молодых ученых российских ученых - кандидатов и докторов наук и ведущих научных школ Российской Федерации».

18. Постановление Правительства Российской Федерации от 9 апреля 2010 года №220 «О мерах по привлечению ведущих ученых в российские образовательные организации высшего образования, научные учреждения и государственные научные центры Российской Федерации».

19. Регионы России. Социально-экономические показатели. 2018: стат. сб. / Росстат. - М., 2018. - 1162 с.

20. Российская социологическая энциклопедия / Под. общ. ред. Г. В. Осипова. - М., 1998. - С. 99.

21. Сенашенко В.С. О престиже профессии «преподаватель высшей школы», ученых 
степеней и ученых званий // Высшее образование в России. - 2017. - №2 (209). C. 36-44.

22. Современная западная социология: Словарь. - М.: Политиздат, 1990. - С. 321-322.

23. Статистика науки и образования. Выпуск 3. Подготовка научных кадров высшей квалификации в России. Инф.-стат. мат. М.: ФГБНУ НИИ РИНКЦЭ, 2018. — 200 с.

24. Терентьев Е.А., Бекова С.К., Малошонок Н.Г. Кризис российской аспирантуры: источники проблем и возможности их преодоления // Университетское управление: практика и анализ. - 2018. — №22. C. 54-66.

25. Указ Президента Российской Федерации от 9 февраля 2009 года №146 «О мерах по усилению государственной поддержки молодых российских ученых — кандидатов и докторов наук».

26. Шестак В.П., Шестак Н.В. Аспирантура как третий уровень высшего образования: дискурсивное поле // Высшее образование в России. - 2015. - №12. - С. 22-34.

27. Шкаратан О.И., Ястребов Г.А. Социально-профессиональная структура населения России. Теоретические предпосылки, методы и некоторые результаты повторных опросов 1994, 2002, 2006 гг. // Мир России. 2007. - №3. - C. 12.

\section{References}

1. Borisova S.N. Teoretiko-metodologicheskie podhody $\mathrm{k}$ izucheniju professij i professional'nyh grupp $\mathrm{v}$ zapadnoj sociologii [Theoretical and methodological approaches to the study of professions and professional groups in Western sociology] // Vestnik Nizhegorodskogo universiteta im. N.I. Lobachevskogo. Ser. Social'nye nauki. — 2012. — №2 (26). Pp. 7-14.

2. Blumer G. Kollektivnoe povedenie [Collective behavior] // Amerikanskaja sociologicheskaja mysl': Teksty [American sociological thought: Texts]. - Moscow, 1994.

3. Gorshkov M. K., Sheregi F. Je. Molodezh' Rossii v zerkale sociologii. K istokam mnogoletnih issledovanij [Youth of Russia in the mirror of sociology. To the origins of long-term research]. - Moscow: FNISCRAN, 2020. St. 393-397.
4. Giddens Je. Ustroenie obshhestva: Ocherki teorii strukturacii [Organization of society: Essays on the theory of structuration]. - 2-e izd. - Moscow, 2005. - $528 \mathrm{p}$.

5. Dezhina I. G. Kadrovye problemy v rossijskoj nauke i iniciativy gosudarstva [Personnel problems in Russian science and state initiatives]// Nauka i naukovedenie [Science and Science studies]. - 2006. - №1. - Pp. 28-34.

6. Dolzhenko R.A., Karpiljanskij V.A., Hadi R.A., DidenkoA.S. Motivacija molodyh uchenyh k nauchno-issledovatel'skoj dejatel'nosti $\mathrm{v}$ rossijskih regional'nyh vuzah [Motivation of young scientists to research activities in Russian regional universities] // Obrazovanie i nauka [Education and Science]. - 2019. - Vol. 21. №9. - Pp. 122-153.

7. Zimmel' $G$. Izbrannoe [Favorites]: in 2 vol. - Moscow, 1996. - Vol. 2. - 1283 p.

8. Indikatory nauki - 2020 [Indicators of science - 2020]: stat. sb. / L.M. Gohberg, K.A. Ditkovskij, E. I. Evnevich i dr.; Nac. issled. un-t «Vysshaja shkola jekonomiki». - Moscow: NIU VShJe, 2020. - 337 p.

9. Innovacionnoe razvitie Rossijskoj federacii v 2019 godu. Analiticheskij otchet FGBNU NII RINKCJe [Innovative development of the Russian Federation in 2019. Analytical report of the RSCCE Research Institute]. 2020. [Jelektronnyj resurs]. — URL: http://www.miiris.ru/digest/analitika_RF.pdf (Date accessed: 23.01.2021).

10. Maloshonok N. G. «Student» ili «molodoj uchenyj»: mnenija nauchnyh rukovoditelej o predpochtitel'noj modeli aspirantskoj podgotovki v rossijskih universitetah [«Student» or «young scientist»: opinions of scientific supervisors about the preferred model of postgraduate training in Russian universities] // Monitoring obshhestvennogo mnenija: Jekonomicheskie i social'nye peremeny [Monitoring of public opinion: Economic and social changes]. - 2019. №4. - Pp. 278-303.

11. Mansurov V.A. Jurchenko O. V. Sociologija professional'nyh grupp: istorija stanovlenija i perspektivy [Sociology of professional groups: history of formation and prospects] // Vestnik Instituta sociologii [Bulletin of the Institute of Sociology]. — 2013. — №7. — Pp. 92-106.

12. Nauchno-innovacionnyj potencial Juzhnogo federal'nogo okruga [Scientific and innovative potential of the Southern Federal Dis- 
trict]: stat. sb. / V.P. Zavaruhin, I. V. Zinov'eva, S.N. Inozemceva et al. - Moscow: IPRAN RAN, 2018. - 155 p.

13. Nauchnye kadry: tendencija snizhenija sohranjaetsja [Scientific personnel: the downward trend persists] [Jelektronnyj resurs] / Jekspress-vypusk ot 25.09.2019 g. [Express issue of 25.09.2019]. Institut statisticheskih issledovanij i jekonomiki znanij NIU VShJe [Institute for Statistical Research and Knowledge Economics. Higher School of Economics]. - URL: https://issek.hse.ru/data/2020/02/07/1574269460/ NTI_N_145_25092019.pdf (Date accessed: 23.01. $\overline{10} 21)$.

14. Osnovy gosudarstvennoj molodezhnoj politiki Rossijskoj Federacii do 2025 goda. Utverzhdena rasporjazheniem Pravitel'stva RF ot 29.11.2014 g. №2403-r [Fundamentals of the State Youth policy of the Russian Federation until 2025. Approved by the decree of the Government of the Russian Federation of 29.11.2014 №2403-r].

15. Oficial'nyj sajt sluzhby gosudarstvennoj statistiki [Official website of the State Statistics Service] [Jelektronnyj resurs]. — URL: https:// rosstat.gov.ru/ (Date accessed: 23.01.2021).

16. Portret sovremennogo rossijskogo aspiranta [Portrait of a modern Russian postgraduate student] / S. K. Bekova, I. A. Gruzdev, Z. I. Dzhafarova, N.G. Maloshonok, E.A. Terent'ev. Moscow: NIU VShJe, 2017. - 60 p.

17. Postanovlenie Pravitel'stva Rossijskoj Federacii ot 27 aprelja 2005 goda №260 «O merah gosudarstvennoj podderzhki molodyh uchenyh rossijskih uchenyh — kandidatov $\mathrm{i}$ doktorov nauk i vedushhih nauchnyh shkol Rossijskoj Federacii») [Resolution of the Government of the Russian Federation №260 of April 27, $2005 \ll$ On measures of State support for young scientists of Russian scientists - candidates and Doctors of Science and leading scientific schools of the Russian Federation»)].

18. Postanovlenie Pravitel'stva Rossijskoj Federacii ot 9 aprelja 2010 goda №220 «O merah po privlecheniju vedushhih uchenyh v rossijskie obrazovatel'nye organizacii vysshego obrazovanija, nauchnye uchrezhdenija i gosudarstvennye nauchnye centry Rossijskoj Federacii» [Resolution of the Government of the Russian Federation №220 of April 9, 2010 «On measures to attract leading Scientists to Russian Educational Organizations of Higher Education, scientific Institutions and State Scientific Centers of the Russian Federation» ].

19. Regiony Rossii. Social'no-jekonomicheskie pokazateli [Regions of Russia. Socioeconomic indicators]. 2018: stat. sb. / Rosstat. Moscow, 2018. - $1162 \mathrm{p}$.

20. Rossijskaja sociologicheskaja jenciklopedija [Russian sociological encyclopedia]/ In G.V. Osipov (eds.). — Moscow, 1998. P. 99.

21. Senashenko V.S. O prestizhe professii «prepodavatel' vysshej shkoly», uchenyh stepenej i uchenyh zvanij [About the prestige of the profession «teacher of higher school», academic degrees and academic titles] // Vysshee obrazovanie v Rossii [Higher education in Russia]. — 2017. — №2 (209). — Pp. 36-44.

22. Sovremennaja zapadnaja sociologija: Slovar' [Modern Western sociology: Dictionary]. - Moscow: Politizdat, 1990. Pp. 321-322.

23. Statistika nauki i obrazovanija [Statistics of science and education]. Issue 3. Podgotovka nauchnyh kadrov vysshej kvalifikacii v Rossii [Training of highly qualified scientific personnel in Russia]. Inf.-stat. mat. - Moscow: FGBNU NII RINKCJe, 2018. - $200 \mathrm{p}$.

24. Terent'ev E. A., Bekova S.K., Maloshonok N.G. Krizis rossijskoj aspirantury: istochniki problem i vozmozhnosti ih preodolenija [The crisis of Russian postgraduate studies: sources of problems and opportunities to overcome them] // Universitetskoe upravlenie: praktika i analiz [University Management: practice and Analysis]. - 2018. - №22. - Pp. 54-66.

25. Ukaz Prezidenta Rossijskoj Federacii ot 9 fevralja 2009 goda №146 «O merah po usileniju gosudarstvennoj podderzhki molodyh rossijskih uchenyh - kandidatov i doktorov nauk» [Decree of the President of the Russian Federation of February 9, 2009 №146 «On measures to strengthen state support for young Russian scientists - candidates and doctors of Science»)].

26. Shestak V.P., Shestak N.V. Aspirantura kak tretij uroven' vysshego obrazovanija: diskursivnoe pole [Postgraduate studies as the third level of higher education: a discursive field] // Vysshee obrazovanie v Rossii [Higher education in Russia]. - 2015. — №12. - Pp. 22-34.

27. Shkaratan O.I., Jastrebov G.A. Social'no-professional'naja struktura naselenija Rossii. 
Teoreticheskie predposylki, metody i nekotorye rezul'taty povtornyh oprosov 1994, 2002, 2006 gg. [Socio-professional structure of the Russian population. Theoretical prerequisites, methods, and some results of repeated surveys in 1994, 2002, and 2006] // Mir Rossii [World of Russia]. — 2007. — №3. - P. 12.

Иванченко Ольга Сергеевна - кандидат социологических наук, доцент Южно-Российского государственного политехнического университета (НПИ) имени М. И. Платова.

Ivanchenko Olga Sergeevna - Candidate of Sociological Sciences, Associate Professor, Platov South Russian State Polytechnic University (NPI).

346428 , г. Новочеркасск, ул. Просвещения, 132 132 Prosveshcheniya st., 346528, Novocherkassk, Russia

E-mail: olga.ivanchenko1509@mail.ru 